\title{
Systemic Immune Effects of Titanium Dioxide Nanoparticles after Repeated Intratracheal Instillation in Rat
}

\author{
Yanyun Fu ${ }^{1}$, Yanqiu Zhang ${ }^{1}$, Xuhong Chang ${ }^{2}$, Yingjian Zhang ${ }^{1}$, Shumei Ma ${ }^{1}$, Jing Sui ${ }^{1}$, \\ Lihong Yin ${ }^{1}$, Yuepu Pu ${ }^{1}$ and Geyu Liang ${ }^{1, *}$
}

1 Key Laboratory of Environmental Medicine Engineering, Ministry of Education, School of Public Health, Southeast University, Nanjing 210009, Jiangsu, China; E-Mails: fckxxz@gmail.com (Y.F.); zyqtx11986@gmail.com (Ya.Z.); zhangyingjian321@gmail.com (Yi.Z.); m837862513@gmail.com (S.M.); sj331622547@gmail.com (J.S.); 1hyin@seu.edu.cn (L.Y.); yppu@seu.edu.cn (Y.P.)

2 Department of Epidemiology and Health Statistics, School of Public Health, Southeast University, Nanjing 210009, Jiangsu, China; E-Mail: cxhpublic@gmail.com

* Author to whom correspondence should be addressed; E-Mail: gyliang@seu.edu.cn; Tel.: +86-25-8327-2565.

Received: 15 February 2014; in revised form: 6 April 2014 / Accepted: 9 April 2014 / Published: 22 April 2014

\begin{abstract}
The potential immune effects of titanium dioxide nanoparticles (nano- $\mathrm{TiO}_{2}$ ) are raising concern. Our previous study verified that nano- $\mathrm{TiO}_{2}$ induce local immune response in lung tissue followed by intratracheal instillation administration. In this study, we aim to evaluate the systemic immune effects of nano- $\mathrm{TiO}_{2}$. Sprague Dawley rats were treated by intratracheal instillation with nano- $\mathrm{TiO}_{2}$ at doses of $0.5,4$, and $32 \mathrm{mg} / \mathrm{kg}$ body weight, micro- $\mathrm{TiO}_{2}$ with $32 \mathrm{mg} / \mathrm{kg}$ body weight and $0.9 \% \mathrm{NaCl}$, respectively. The exposure was conducted twice a week, for four consecutive weeks. Histopathological immune organs from exposed animals showed slight congestion in spleen, generally brown particulate deposition in cervical and axillary lymph node. Furthermore, immune function response was characterized by increased proliferation of $\mathrm{T}$ cells and $\mathrm{B}$ cells following mitogen stimulation and enhanced natural killer (NK) cell killing activity in spleen, accompanying by increased number of $\mathrm{B}$ cells in blood. No significant changes of Th1-type cytokines (IL-2 and INF- $\gamma$ ) and Th2-type cytokines (TNF- $\alpha$ and IL-6) were observed. Intratracheal exposure to nano- $\mathrm{TiO}_{2}$ may be one of triggers to be responsible for the systemic immune response. Further study is needed to confirm long-lasting lymphocyte responses and the potential mechanisms.
\end{abstract}


Keywords: nano- $\mathrm{TiO}_{2}$; systemic immune response; lymphocyte proliferation; cytokines

\section{Introduction}

Nanomaterials are engineered structures with at least one dimension of 100 nanometers or less [1]. With the rapid development of the nanotechnology industry, more and more nanoparticles have generally come into our life through their different approaches. At the same time, safety in nanoparticles is attracting more and more attention.

Because of its unusual physicochemical properties, titanium dioxide nanoparticles (nano- $\left.\mathrm{TiO}_{2}\right)$ have a wide range of applications in many fields, including cosmetics, pharmaceutical, and paint industries. Previous in vivo studies have shown that nano- $\mathrm{TiO}_{2}$ particles can easily travel throughout the body, penetrate cell membranes, lodge in mitochondria, deposit in target organs, and may cause different degrees of organ damage, including lung, liver, kidney and brain [2-10]. Some in vitro studies also have shown that nano- $\mathrm{TiO}_{2}$ can cause oxidative stress, DNA damage and enzymatic activity changes, followed by cell apoptosis or necrosis [11-13]. Recently, it has been reported that exposure to nano- $\mathrm{TiO}_{2}$ in experimental animals can damage pulmonary macrophages, induce splenocyte apoptosis, promote reactive oxygen species (ROS) accumulation, change cytokine production and decrease immune function [14-18]. However, the researches on immunotoxicity of nano- $\mathrm{TiO}_{2}$ are still rarely reported.

Our previous study evaluated the local immune function of rat exposed to nano- $\mathrm{TiO}_{2}$ by intratracheal instillation [19]. The phagocytic ability of the pulmonary alveolar macrophages was increased when they were exposed to low-dose of nano- $\mathrm{TiO}_{2}$ and decreased when they were exposed to high dose of nano- $\mathrm{TiO}_{2}$. In addition, nano- $\mathrm{TiO}_{2}$ damaged the cellular structure, reduced chemotactic ability, decreased expression of both Fc receptors and major histocompatibility complex (MHC)-class II molecules and increased nitric oxide (NO) and tumor necrosis factor alpha (TNF- $\alpha$ ) secretion of macrophages, which suggest that nano- $\mathrm{TiO}_{2}$ disrupt the functions of macrophages associated with pulmonary non-specific and specific immunity. On that basis, this study was conducted to assess systemic immune response to repeated pulmonary nano- $\mathrm{TiO}_{2}$ exposure in rats.

\section{Results}

\subsection{Histopathological Examination}

Histopathological evaluation was performed in various immune organs including spleen, cervical and axillary lymph node and thymus (Figure 1). Rats from high-dose nano- $\mathrm{TiO}_{2}$ exposure showed slight congestion of the splenic sinus. In cervical and axillary lymph node, the brown particulate was generally aggregated in different sizes in rat exposed to $32 \mathrm{mg} / \mathrm{kg}$ nano- $\mathrm{TiO}_{2}$. No histopathological changes were found in thymus in all groups. 
Figure 1. Histopathology of the tissue in Sprague-Dawley (SD) rat caused by an intratracheal instillation with nano-TiO2 for 28 days $(200 \times)$. Hematoxylin and eosin stains of spleen (a1-a5); lymph node (b1-b5) and thymus (c1-c5) tissues of rat. Black arrows point to brown particulate deposition.

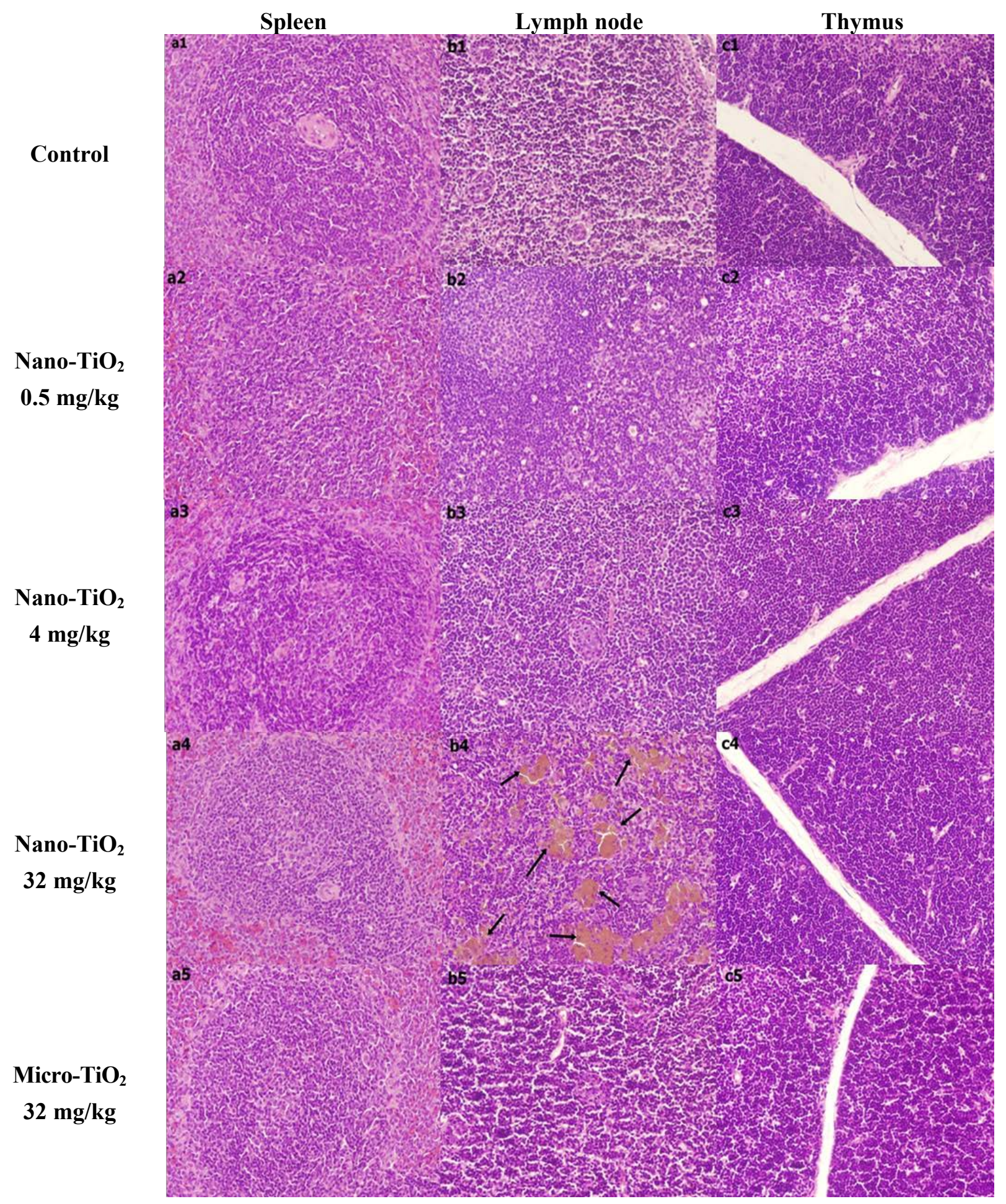

\subsection{Mitogen Stimulated Lymphocyte Proliferation Assay}

In this assay, lipopolysaccharide (LPS) and concanavalin A (ConA) are usually used to analyze the proliferation of B- and T-lymphocyte, respectively. The effects of treatment with nano- $\mathrm{TiO}_{2}$ particles 
on spleen-derived lymphocyte proliferation in the rat are shown in Figure 2. As the exposure dose of nano- $\mathrm{TiO}_{2}$ was increased, the $\mathrm{B}$ - and $\mathrm{T}$-lymphocyte proliferation stimulated by mitogen was increased. Significant difference in the B- and T-lymphocyte proliferation ability was found in the groups exposed to 4 and $32 \mathrm{mg} / \mathrm{kg}$ nano- $\mathrm{TiO}_{2}$ compared with the control group $(p<0.05)$.

Figure 2. Lymphocyte proliferation in the spleen from rats exposed to nano- $\mathrm{TiO}_{2}$ for 28 days by intratracheal instillation. * represents significantly different from control group $(p<0.05)$.

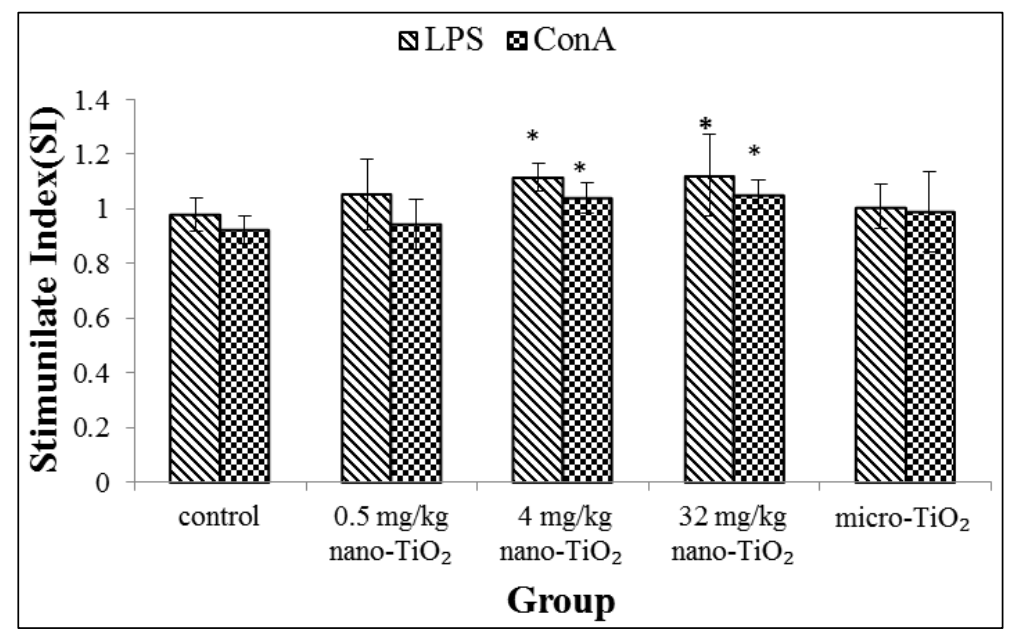

\subsection{Natural Killer (NK) Cell Activity Assay}

The effects of treatment with nano- $\mathrm{TiO}_{2}$ particles on spleen-derived natural killer (NK) cell activity in the rat are shown in Figure 3. The NK cell activity was increased with the rise of exposure dose of nano- $\mathrm{TiO}_{2}$ particles. Significant difference in the NK cell activity was found in the groups exposed to $32 \mathrm{mg} / \mathrm{kg}$ nano- $\mathrm{TiO}_{2}$ compared with the control group $(p<0.05)$.

Figure 3. Natural killer (NK) cell activity in the spleen from rats exposed to nano- $\mathrm{TiO}_{2}$ for 28 days by intratracheal instillation. * represents significantly different from control group $(p<0.05)$.

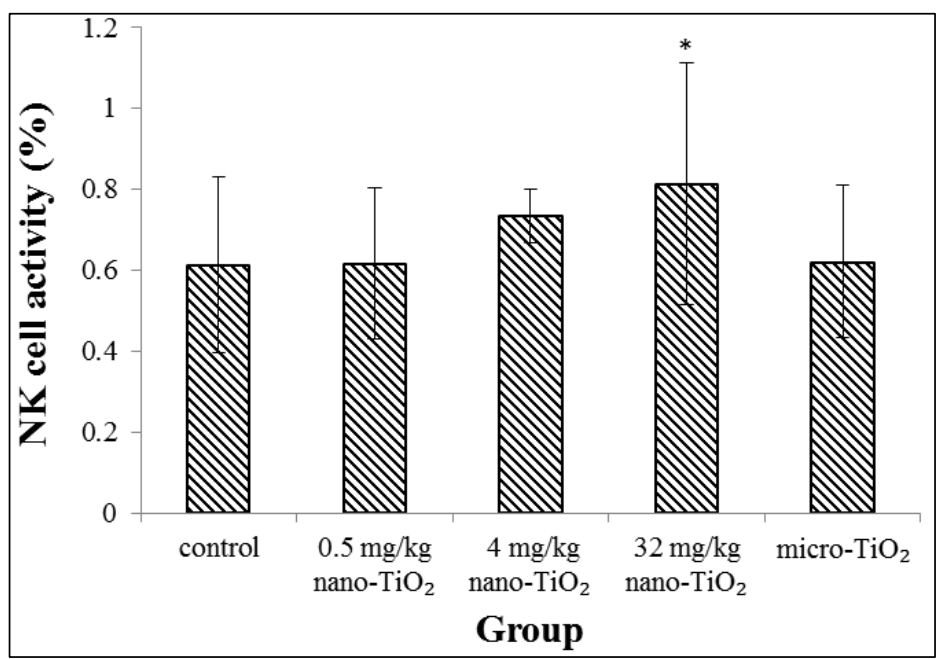




\subsection{Lymphocyte Population of Peripheral Blood}

The results of lymphocyte population distribution in the peripheral blood of rat treated with nano- $\mathrm{TiO}_{2}$ are shown in Figure 4. The B-lymphocyte population distribution was increased with the rise of exposure dose of nano- $\mathrm{TiO}_{2}$. A significant increase of B-lymphocyte distribution was found in the groups exposed to $32 \mathrm{mg} / \mathrm{kg}$ nano- $\mathrm{TiO}_{2}$ compared with the control group $(p<0.05)$. No significant differences in distribution of T-lymphocyte populations and NK cell populations were found between exposure groups and control group $(p>0.05)$.

Figure 4. Lymphocyte population distribution of peripheral blood from rats exposed to nano- $\mathrm{TiO}_{2}$ for 28 days by intratracheal instillation. * represents significantly different from control group $(p<0.05)$.

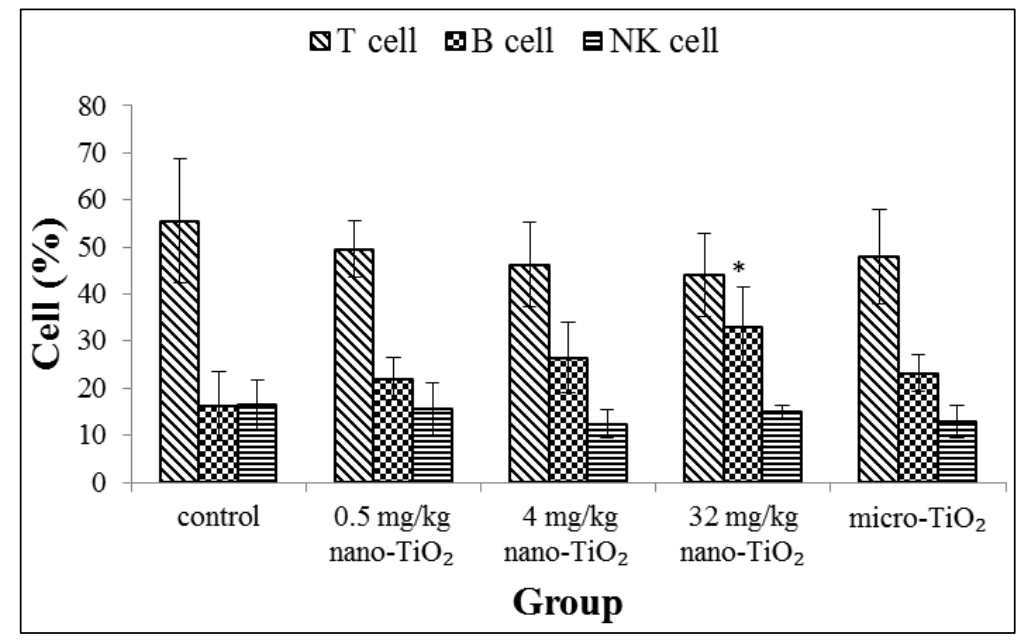

\subsection{Cytokine Production in Blood}

The effects of nano- $\mathrm{TiO}_{2}$ on the production of cytokines in blood were evaluated. No significant changes of IL-2, IL-6, IFN- $\gamma$ and TNF- $\alpha$ expression were observed (Figure 5).

\section{Discussion}

Increased use of artificial nanoparticles in a wide range has introduced a potential inhaled pollutant. Although the reports on toxicity of nanoparticles are now increasing, immunity-related responses of nanoparticles have not been well studied. In this study, we focused on the systemic immune response induced by repeated exposure of titanium dioxide nanoparticles, involved in immune organ formation, lymphocyte proliferation, lymphocyte distribution and cytokine induction.

It has been known that the toxicological effects of nanoparticles are closely related to their specific physicochemical properties. Nano- $\mathrm{TiO}_{2}$ seemed to be agglomerated in solution state, which might influence evaluation of biological response of nano- $\mathrm{TiO}_{2}$. In our study, we found that $0.9 \% \mathrm{NaCl}$ buffer is a suitable solution for preparation of nano- $\mathrm{TiO}_{2}$ dispersions and subsequent biological investigation because the solution buffer with $0.9 \% \mathrm{NaCl}$ maintained a better dispersion. $\mathrm{Nano}^{-\mathrm{TiO}_{2}}$ suspension solution used for the intratracheal instillation in this study showed less aggregation. 
The mean diameter of the agglomerated nano- $\mathrm{TiO}_{2}$ was about $200 \mathrm{~nm}$, which was not micrometer level, but nano level.

Figure 5. Cytokines expression in the peripheral blood from rats exposed to nano- $\mathrm{TiO}_{2}$ for 28 days by intratracheal instillation. (A) the changes of IL-2 expression; (B) the changes of IL-6 expression; (C) the changes of IFN- $\gamma$ expression; and (D) the changes of TNF- $\alpha$ expression.

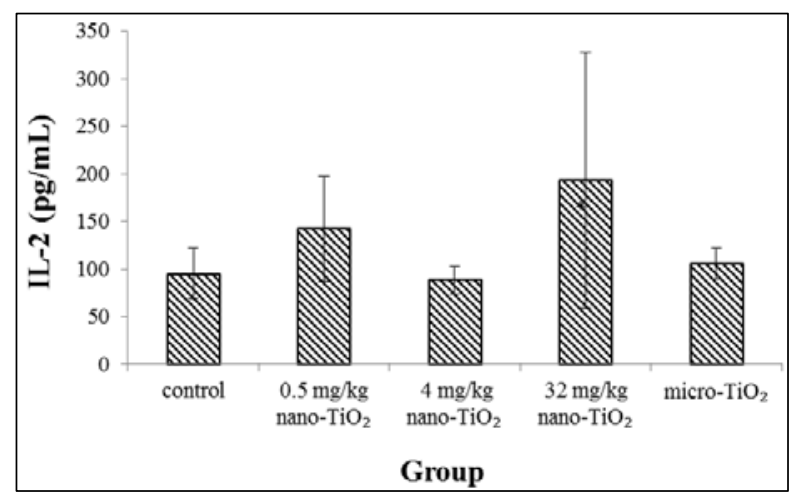

(A)

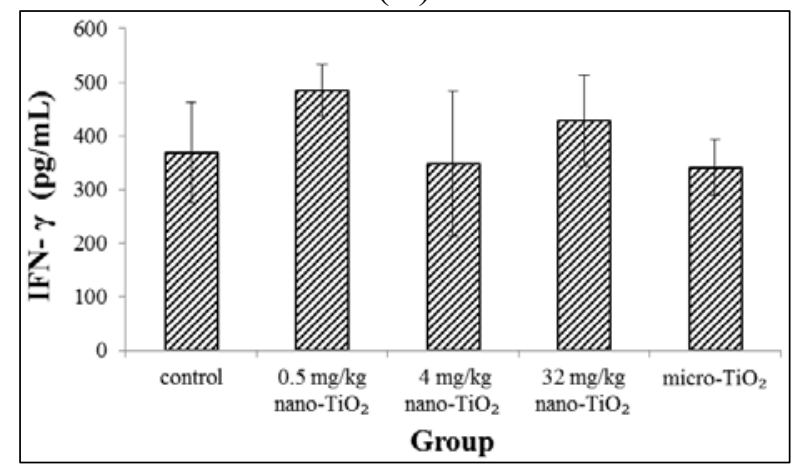

(C)

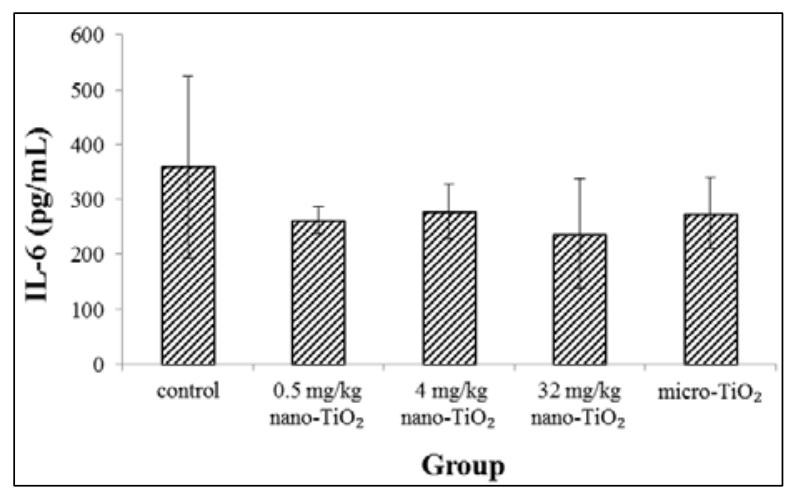

(B)

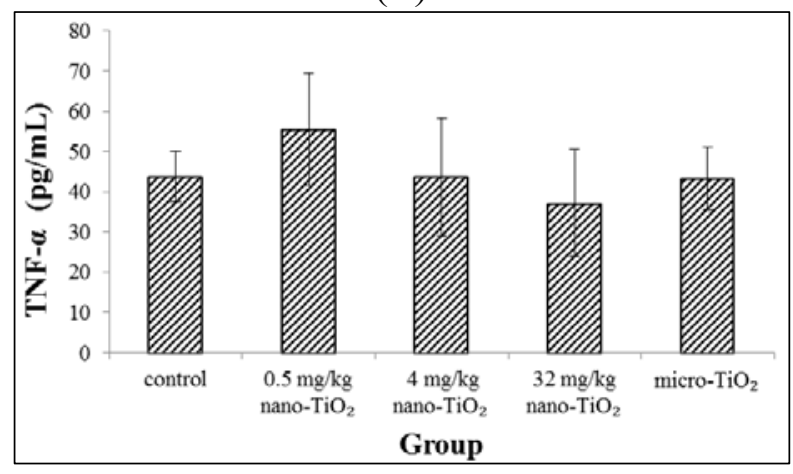

(D)

The immune organs play a vital role during the body defense progress for xenobiotic. Spleen is the largest lymphoid organ and important in both innate and adaptive immune. A few evidences have been reported that nano- $\mathrm{TiO}_{2}$ could produce spleen response. $\mathrm{Li}$ et al. reported that nano- $\mathrm{TiO}_{2}$ exposure at doses of 50 and $150 \mathrm{mg} / \mathrm{kg}$ by intraperitoneal injection for consecutive 45 days induced obvious congestion and lymph nodule proliferation in the mouse spleen [18]. Sang et al. showed that doses of 2.5, 5 and $10 \mathrm{mg} / \mathrm{kg}$ nano- $\mathrm{TiO}_{2}$ administrated by intragastric injection for 90 days produced congestion, white pulp rarely, disperative replication of white pulp and anemia of red pulp in the mouse spleen [17]. Chen et al. found that a large number of $\mathrm{TiO}_{2}$ particles accumulated in spleen, and caused a mass of neutrophilic cells in spleen tissues and a severe spleen lesion after nano- $\mathrm{TiO}_{2}$ exposure with higher doses $(324-2592 \mathrm{mg} / \mathrm{kg})$ by an intraperitoneal injection for 7 days [8]. Wang et al. observed that 14 days after a large dose of $5 \mathrm{~g} / \mathrm{kg}$ of nano- $\mathrm{TiO}_{2}$ was administrated by a single intragastric injection, resulted in splenic accumulation of nano- $\mathrm{TiO}_{2}$, but did not cause abnormal pathology changes in the mouse spleen [7]. The histopathological results of this study showed that the repeated intratracheal instillation administration of various doses of nano- $\mathrm{TiO}_{2}$ can induce slight congestion of spleen, consistent with above studies. We did not observe the severe injury of spleen, which may be due to the exposure dose or time of nano- $\mathrm{TiO}_{2}$ (no more than $32 \mathrm{mg} / \mathrm{kg}$, 28 days) in our study which was lower than that in other studies. In addition, we also observed that 
nano- $\mathrm{TiO}_{2}$ may cause significant accumulation in the rat lymph node, while there are no abnormal pathology changes in the micro- $\mathrm{TiO}_{2}$ exposure group. Van Ravenzwaay et al. also reported nano- $\mathrm{TiO}_{2}$ (14\% rutile, $86 \%$ anatase) accumulation in lymphoid tissue after inhalation exposure in the rat [20]. These results indicated that inhaled nano- $\mathrm{TiO}_{2}$ could translocate throughout the body quickly and tend to accumulate in immune organ, which possibly through uptake by migratory antigen presenting cells, because many toxicological studies have observed that macrophages or foreign-body giant cells appeared in lung tissue as exposure doses increased [21,22].

We have previously reported altered local immune cell function following intratracheal instillation of nano- $\mathrm{TiO}_{2}$. It was observed that nano- $\mathrm{TiO}_{2}$ were uptake in pulmonary macrocrophages, consistent with pulmonary macrophages as the first-line defense against inhalation of particles. Function detection showed that exposures to nano- $\mathrm{TiO}_{2}$ increased the phagocytic ability of the pulmonary macrophages [19]. In this study, immune function measurements on spleen-derived cells showed increased proliferation of $\mathrm{T}$ cells and $\mathrm{B}$ cells following mitogen stimulation and enhanced NK cell killing activity, which was accompanied by increased B cells number in blood. Lymphocyte proliferation is an important phase in the immune response. The results indicated that nano- $\mathrm{TiO}_{2}$ could trigger systemic immune responses. Recent studies have revealed that exposure to nanoparticles can stimulate immune cell. Lee et al. reported that mesoporous silica nanoparticles led to significant splenocyte proliferation to the lymphocyte mitogens when administered by intraperitoneal injection in female BALB/c mice for 4 weeks [23]. Park et al. showed an increase in numbers of B cells in splenocytes and in blood after mice were treated with nano- $\mathrm{TiO}_{2}$ by a single intratracheal instillation [24]. Wang et al. researched that increases $\mathrm{T}$ cells in the spleen of C57BL/6 mice dependent on nanomaterial comparison of graphene and carbon nanotubes [25]. Gustafsson et al. discussed an increase in numbers of NK cells in lung after exposure to nano- $\mathrm{TiO}_{2}$ by intratracheal installation [26]. However, Sang et al. noted lymphocytes (including T, B lymphocyte and NK cell) of whole blood in mice were significantly decreased following nano- $\mathrm{TiO}_{2}$ exposure for 90 consecutive days by intragastric administrations [17]. Differences in response may be attributed to route of administration, dose and exposure time.

Cytokines are very important regulators of the immune responses and serve to maintain balance of immune system. After adaptive immune system was triggered, the activated $\mathrm{T}$ cells were differentiated into helper $\mathrm{T}$ cells and cytotoxic $\mathrm{T}$ cells. Then, helper $\mathrm{T}$ cells were differentiated into Th1 cell and Th2 cell. Th1 and Th2 cell trigger cellular and humoral immunity by secret cytokines, respectively. It was reported that IL-2 and IFN- $\gamma$ levels in serum levels was significantly increased in rat treated with nano- $\mathrm{TiO}_{2}$, indicating that nano- $\mathrm{TiO}_{2}$ exposure may trigger $\mathrm{Th} 1$ immune response [26]. However, another recently report showed that nano- $\mathrm{TiO}_{2}$ induced a $\mathrm{Th} 2$ cell response in mice [27]. In this study, we analyzed the Th1-type cytokines (IL-2 and INF- $\gamma$ ) and Th2-type cytokines (TNF- $\alpha$ and IL-6). However, no significant changes of these cytokines expression were observed throughout the experimental period. The discrepancy is likely explained by species differences, nano- $\mathrm{TiO}_{2}$ particle differences, especially observation time differences. Gustafsson et al. reported that most cytokine expression at days 1-2 and a second response at day 16 of TNF- $\alpha$ after nano- $\mathrm{TiO}_{2}$ exposure [26]. Park et al. also noted IL-2 and IL-4 were increased in a time-dependent manner [24]. In the future, dynamic investigations will be performed to understand the mechanism between Th-related cytokines and systemic immune response with nano- $\mathrm{TiO}_{2}$ exposure. 


\section{Experimental Section}

\subsection{Preparation of Nano-TiO}

Manufactured nano- $\mathrm{TiO}_{2}$ (P25) was purchased from Degussa Corporation (Hanau, Germany). Micro- $\mathrm{TiO}_{2}$ of size 1-2 $\mu \mathrm{m}$ was purchased from Beijing DK nano technology Co., Ltd. (Beijing, China). According to the information provided by the supplier, nano- $\mathrm{TiO}_{2}$ is a fine white powder with mean diameter of $21 \mathrm{~nm}$ (Table 1). The characteristics of the nano- $\mathrm{TiO}_{2}$ were found in our previously study [28]. Nano- $\mathrm{TiO}_{2}$ was heated to $121{ }^{\circ} \mathrm{C}$ for $20 \mathrm{~min}$ to reduce the risk of bacterial contamination. $\mathrm{TiO}_{2}$ powder was dispersed into an aqueous solution buffered with $0.9 \%(w / v)$ sodium chloride $(\mathrm{NaCl})$ solution. For sufficiently disperse particles, solutions containing $\mathrm{TiO}_{2}$ particles were sonicated for 5 min at 30\% amplitude by Sonicator ultrasonic processor (Model S-4000, Misonix, Inc., Farmingdale, NY, USA). Size distribution of nano- $\mathrm{TiO}_{2}$ suspension was also analyzed using Malvern Instruments Zetasizer Nano ZS90 (Malvern Instruments Ltd., Worcestershire, UK). The mean diameter of nano- $\mathrm{TiO}_{2}$ suspended in $0.9 \% \mathrm{NaCl}$ was about $200 \mathrm{~nm}$ (Figure 6).

Table 1. Characterization of $\mathrm{TiO}_{2}$ particles.

\begin{tabular}{ccc}
\hline Particle & Nano-TiO $_{2}$ & Micro-TiO $_{2}$ \\
\hline supplier & Degussa & DK nano \\
size $(\mathrm{nm})$ & $21 \mathrm{~nm}$ & $1-2 \mu \mathrm{m}$ \\
crystalline form & $80 \%$ anatase $/ 20 \%$ rutile & anatase \\
specific surface area $\left(\mathrm{m}^{2} / \mathrm{g}\right)$ & 50 & 18 \\
purity $(\%)$ & $>99.5$ & $>99.9$ \\
$Z$-Average (d.nm) & 195.2 & - \\
PDI * & 0.066 & - \\
\hline
\end{tabular}

* The polydispersity index (PDI) describes the width of the particle size distribution.

\subsection{Animals and Treatment}

Male Sprague-Dawley (SD) rats, with an average body weight of 200-220 g, were provided from Liaoning Chang Sheng Biotechnology Co., Ltd. (Benxi, China). The animal room was maintained at $20 \pm 2{ }^{\circ} \mathrm{C}, 60 \% \pm 10 \%$ relative humidity and a $12 \mathrm{~h}$ light/dark cycle. Rats were acclimatized for 5 days before experimentation. Procedures complied with the national regulations related to animal welfare. Forty rats were randomly divided into five groups. The control group was treated with $0.9 \% \mathrm{w} / \mathrm{w} \mathrm{NaCl}$ solution. The experimental groups were treated with $0.5,4,32 \mathrm{mg} / \mathrm{kg}$ nano- $\mathrm{TiO}_{2}$ and $32 \mathrm{mg} / \mathrm{kg}$ micro- $\mathrm{TiO}_{2}$, respectively. All groups were performed to repeated exposure (twice a week, for four consecutive weeks) by intratracheal instillation. The volume of intratracheal instillation was $0.1 \mathrm{~mL} / 100 \mathrm{~g}$. Four weeks later, the rats were sacrificed by exsanguination via the abdominal aorta after being anesthetized by ether. Spleen, cervical and axillary lymph node, thymus, and whole blood were collected for further assay. 
Figure 6. Particle size distribution of nano- $\mathrm{TiO}_{2}$ in $\mathrm{NaCl}$ suspension.

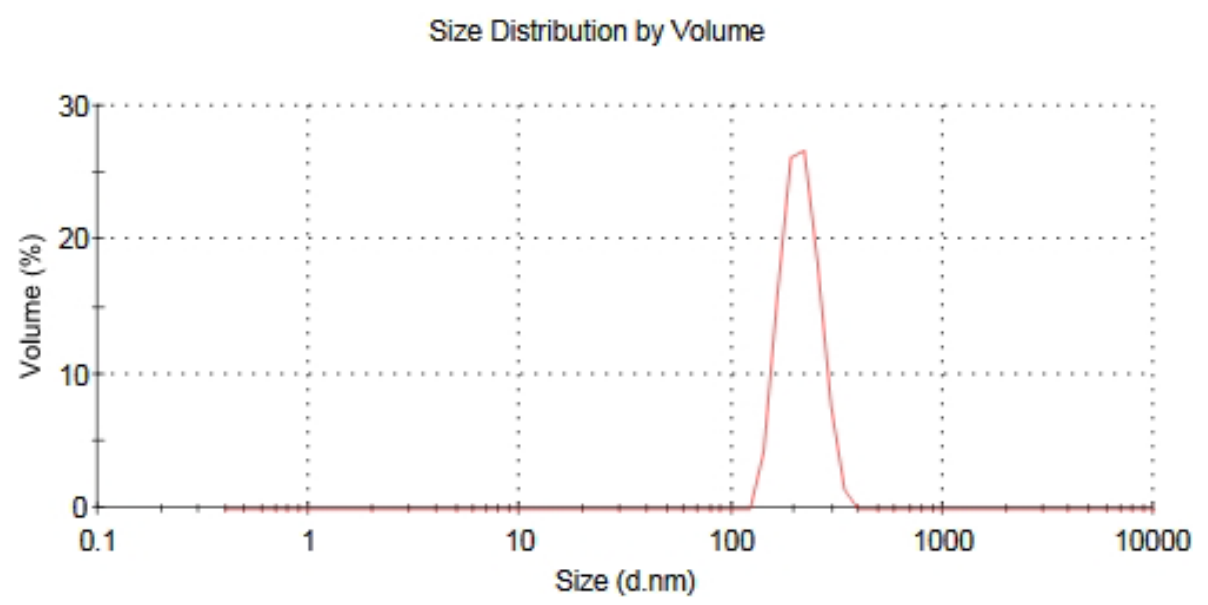

\subsection{Histopathological Examination}

All histopathological tests were performed using standard lab-oratory procedures. The spleen, lymph node and thymus tissues were fixed in a $10 \%$ formalin solution for one week. Then, the tissues were embedded in paraffin blocks, and then sectioned into $5 \mu \mathrm{m}$ slices and mounted on glass slides. After hematoxylin-eosin (HE) staining, the slides were examined using an optical microscope (Olympus, Tokyo, Japan). The identity and analysis of the pathology slides were blind to the pathologist.

\subsection{Preparation of Spleen-Derived Lymphocyte Populations}

Single-cell lymphocyte populations were prepared from the spleen of rat. Spleen was dissociated on a steel mesh in Hanks' balanced salt solution (Beyotime, Nantong, China). The splenocyte that passed through the mesh were centrifuged at $2000 \mathrm{rpm}$ for $5 \mathrm{~min}$. The supernatant was discarded and cells were resuspended in the Hanks' medium. The red blood cell lysis buffer (Beyotime, Nantong, China) was added to lyse the erythrocytes. Then, the cell suspension was filtered and washed to remove cell debris. Finally, cells were resuspended in RPMI1640 [with 10\% fetal bovine serum (FBS)] (Hyclone, Victoria, Australia). Cell viability was assessed using the trypan blue exclusion test and routinely found to contain $<5 \%$ dead cells. The cell density was adjusted to $5 \times 10^{6}$ cells $/ \mathrm{mL}$ for further assay.

\subsection{Mitogen Stimulated Lymphocyte Proliferation Assay}

Lymphocyte proliferation responses to mitogens (lipopolysaccharide, LPS and concanavalin A, ConA) were evaluated with the CCK- 8 assay. For each spleen sample, lymphocyte were placed into a U-bottom 96-well plate in triplicate at a density of $1 \times 10^{6}$ cells $/ \mathrm{mL}$ with a total volume of $90 \mu \mathrm{L}$. $10 \mu \mathrm{L}$ LPS (L2630, Sigma, St. Louis, MO, USA) or ConA (C2010, Sigma, St. Louis, MO, USA) at a concentration of $20 \mu \mathrm{g} / \mathrm{mL}$ was added to wells, respectively. Supplemented RPMI1640 media were added to control wells. Plates were briefly mixed on a plate shaker and then placed in a $5 \% \mathrm{CO}_{2}, 37{ }^{\circ} \mathrm{C}$ incubator for $72 \mathrm{~h}$. Then, CCK-8 was added and incubated for an additional $4 \mathrm{~h}$. Following incubation, spectrophotometric data were measured using an automatic microplate reader (type MRX, Dynex Technologies Company, Chantilly, VA, USA) at a wavelength of $450 \mathrm{~nm}$. 


\subsection{Natural Killer (NK) Cell Activity Assay}

NK cell activity was evaluated by lactate dehydrogenase (LDH) release assay. Human erythroleukemia cell line K-562 (Chinese Academy of Sciences, Shanghai, China) was used as a target cell in this assay because it is sensitive to the cytotoxicity of NK cells. K562 cells were routinely cultured in RPMI1640 medium (with 10\% FBS) (Hyclone, Victoria, Australia) and were plated at a concentration of $1 \times 10^{5}$ cells/mL in U-bottom 96-well plates (Corning, Shanghai, China). Splenocytes were plated at $5 \times 10^{6}$ cells $/ \mathrm{mL}$ for an effector to target ratio (E:T) of 50:1. Two controls were placed for the assay, including a spontaneous control (target cells + RPMI1640 medium) and a maximum spontaneous control (target cells $+1 \%$ NP40 lysis buffer). Plates were incubated at $5 \% \mathrm{CO}_{2}, 37{ }^{\circ} \mathrm{C}$ for $20 \mathrm{~h}$ and then centrifuged at $2000 \mathrm{rpm}$ for $5 \mathrm{~min}$. One hundred $\mu \mathrm{L}$ the supernatant was removed to the new plate, followed by $100 \mu \mathrm{L}$ LDH matrix liquid and $30 \mu \mathrm{L} 1 \mathrm{M} \mathrm{HCL}$ was added to each well. Finally, optical density $(O D)$ was measured using an automatic microplate reader at a wavelength of $490 \mathrm{~nm}$. Percentage of cytotoxicity was calculated by:

$$
\text { Cytotoxicity } \%=(\text { sample } O D-\text { spontaneous } O D) /(\text { maximum } O D-\text { spontaneous } O D) \times 100 \%
$$

\subsection{Lymphocyte Population Analyses in Blood}

Lymphocyte population distribution in peripheral blood was examined using flow cytometry method. All monoclonal antibodies were purchased from eBioscience (San Diego, CA, USA). T cells (CD3, eBioG4.18), B cells (CD45RA, OX33), NK cells (CD161, clone 10/78) were identified using directly conjugated anti-rat antibody [29]. Erythrocytes in the blood were lysed with red blood cell lysis buffer. Then, cells were washed with PBS buffer. Finally, each sample was fixed with $0.1 \%$ paraformaldehyde and analyzed by flow cytometry (BD Biosciences, Franklin Lakes, NJ, USA).

\subsection{Cytokines Analyses in Blood}

Serum samples were obtained from peripheral blood by centrifugation at $3000 \mathrm{rpm}$ for $10 \mathrm{~min}$ at $4{ }^{\circ} \mathrm{C}$ and immediately frozen at $-80^{\circ} \mathrm{C}$ for further detection. IL-2, IL-6, IFN- $\gamma$ and TNF- $\alpha$ were measured by a MILLIPLEX MAP Rat Cytokine Kit (Millipore, Billerica, MA, USA) according to the manufacturers' instructions.

\subsection{Statistical Analysis}

Statistical analysis was done by SPSS16.0 software (SPSS Inc., Chicago, IL, USA). The differences of means among groups were analyzed by One-way analysis of variance method (ANOVA). The comparisons between experimental group and control group were made by LSD test. The results were regarded as statistical significant as $p<0.05$.

\section{Conclusions}

In summary, nano-TiO2 induced pathological changes of spleen and lymph node, including slight congestion and brown particulate accumulation. Furthermore, increased proliferation of spleen-derived $\mathrm{T}$ cells and $\mathrm{B}$ cells following mitogen stimulation and enhanced NK cell killing activity were observed 
by repeated instillation of nano- $\mathrm{TiO}_{2}$. Number of $\mathrm{B}$ cell was also increased in the blood. The result suggested that nano- $\mathrm{TiO}_{2}$ may be one of triggers to be responsible for the systemic immune response. The study served to improve the overall understanding of the immune response associated with inhalable nano- $\mathrm{TiO}_{2}$ and provided new strategy for risk assessment of nano- $\mathrm{TiO}_{2}$. More work needs to be done to evaluate the potential mechanism for this response.

\section{Acknowledgments}

The authors thank the support from the National Natural Science Foundation (No. 81172618); State Key Program for Basic Research of China (No. 2011CB933404); Qing Lan Project (2012); 333 project of Jiangsu Province (2012); Liu Da Ren Cai Gao Feng Project of Jiangsu Province (2013-WSW-053); and the Fundamental Research Funds for the Central Universities (CXZZ13_0134).

\section{Author Contributions}

Conception and design: Geyu Liang, Yanyun Fu; Administrative support: Lihong Yin, Yuepu Pu; Animal experiment and data collection: Yanyun $\mathrm{Fu}$, Yanqiu Zhang, Xuhong Chang, Yingjian Zhang, Shumei Ma, Jing Sui; Data analysis and drafting of manuscript: Geyu Liang, Yanyun Fu; Critical revisions/Supervision: Geyu Liang, Yanyun Fu, Lihong Yin, Yuepu Pu.

\section{Conflicts of Interest}

The authors declare no conflict of interest.

\section{References}

1. Nel, A.; Xia, T.; Madler, L.; Li, N. Toxic potential of materials at the nanolevel. Science 2006, $311,622-627$.

2. Chen, H.W.; Su, S.F.; Chien, C.T.; Lin, W.H.; Yu, S.L.; Chou, C.C.; Chen, J.J.; Yang, P.C. Titanium dioxide nanoparticles induce emphysema-like lung injury in mice. FASEB J. 2006, 20, 2393-2395.

3. Liu, R.; Yin, L.; Pu, Y.; Liang, G.; Zhang, J.; Su, Y.; Xiao, Z.; Ye, B. Pulmonary toxicity induced by three forms of titanium dioxide nanoparticles via intra-tracheal instillation in rats. Prog. Nat. Sci. 2009, 19, 573-579.

4. Halappanavar, S.; Jackson, P.; Williams, A.; Jensen, K.A.; Hougaard, K.S.; Vogel, U.; Yauk, C.L.; Wallin, H. Pulmonary response to surface-coated nanotitanium dioxide particles includes induction of acute phase response genes, inflammatory cascades, and changes in microRNAs: A toxicogenomic study. Environ. Mol. Mutagen. 2011, 52, 425-439.

5. Cui, Y.; Liu, H.; Ze, Y.; Zengli, Z.; Hu, Y.; Cheng, Z.; Cheng, J.; Hu, R.; Gao, G.; Wang, L.; et al. Gene expression in liver injury caused by long-term exposure to titanium dioxide nanoparticles in mice. Toxicol. Sci. 2012, 128, 171-185.

6. Liu, H.; Ma, L.; Liu, J.; Zhao, J.; Yan, J.; Hong, F. Toxicity of nano-anatase $\mathrm{TiO}_{2}$ to mice: Liver injury, oxidative stress. Toxicol. Environ. Chem. 2010, 92, 175-186. 
7. Wang, J.; Zhou, G.; Chen, C.; Yu, H.; Wang, T.; Ma, Y.; Jia, G.; Gao, Y.; Li, B.; Sun, J.; et al. Acute toxicity and biodistribution of different sized titanium dioxide particles in mice after oral administration. Toxicol. Lett. 2007, 168, 176-185.

8. Chen, J.; Dong, X.; Zhao, J.; Tang, G. In vivo acute toxicity of titanium dioxide nanoparticles to mice after intraperitioneal injection. J. Appl. Toxicol. 2009, 29, 330-337.

9. Gui, S.; Zhang, Z.; Zheng, L.; Cui, Y.; Liu, X.; Li, N.; Sang, X.; Sun, Q.; Gao, G.; Cheng, Z.; et al. Molecular mechanism of kidney injury of mice caused by exposure to titanium dioxide nanoparticles. J. Hazard. Mater. 2011, 195, 365-370.

10. Ze, Y.; Hu, R.; Wang, X.; Sang, X.; Ze, X.; Li, B.; Su, J.; Wang, Y.; Guan, N.; Zhao, X.; et al. Neurotoxicity and gene-expressed profile in brain-injured mice caused by exposure to titanium dioxide nanoparticles. J. Biomed. Mater. Res. 2014, 102, 470-478.

11. Park, E.J.; Yi, J.; Chung, K.H.; Ryu, D.Y.; Choi, J.; Park, K. Oxidative stress and apoptosis induced by titanium dioxide nanoparticles in cultured BEAS-2B cells. Toxicol. Lett. 2008, 180, 222-229.

12. Zhao, J.; Bowman, L.; Zhang, X.; Vallyathan, V.; Young, S.H.; Castranova, V.; Ding, M. Titanium dioxide $\left(\mathrm{TiO}_{2}\right)$ nanoparticles induce JB6 cell apoptosis through activation of the caspase-8/Bid and mitochondrial pathways. J. Toxicol. Environ. Health 2009, 72, 1141-1149.

13. Wang, J.J.; Sanderson, B.J.; Wang, H. Cyto- and genotoxicity of ultrafine $\mathrm{TiO}_{2}$ particles in cultured human lymphoblastoid cells. Mutat. Res. 2007, 628, 99-106.

14. Li, Y.; Liu, R.; Liang, G.; Pu, Y.; Yin, L. Effect of the transbronnchial intoxication of $\mathrm{TiO}_{2}$ nanoparticles on immune function of pulmonary alveolar macrophages in rat. J. Environ. Occup. Med. 2008, 25, 156-158.

15. Liu, H.; Yang, D.; Zhang, H.; Yang, H.; Zhang, W.; Liu, L.; Lin, Z.; Yan, J.; Lin, B.; Xi, Z. Immunity toxic effects induced by three kinds of nanomaterials in rat. J. Prev. Med. Chin. PLA 2010, 28, 163-166.

16. Liu, H.; Zhang, H.; Yang, D.; Yang, H.; Lin, Z.; Yan, J.; Lin, B.; Tian, L.; Huang, J.; Xi, Z. The effect of nanoparticles on T-lymphocyte populations of peripheral blood in rat. J. Environ. Occup. Med. 2011, 29, 320-323.

17. Sang, X.; Zheng, L.; Sun, Q.; Li, N.; Cui, Y.; Hu, R.; Gao, G.; Cheng, Z.; Cheng, J.; Gui, S. The chronic spleen injury of mice following long-term exposure to titanium dioxide nanoparticles. J. Biomed. Mater. Res. 2012, 100, 894-902.

18. Li, N.; Duan, Y.; Hong, M.; Zheng, L.; Fei, M.; Zhao, X.; Wang, J.; Cui, Y.; Liu, H.; Cai, J. Spleen injury and apoptotic pathway in mice caused by titanium dioxide nanoparticules. Toxicol. Lett. 2010, 195, 161-168.

19. Liu, R.; Zhang, X.; Pu, Y.; Yin, L.; Li, Y.; Zhang, X.; Liang, G.; Li, X.; Zhang, J. Small-sized titanium dioxide nanoparticles mediate immune toxicity in rat pulmonary alveolar macrophages in vivo. J. Nanosci. Nanotechnol. 2010, 10, 5161-5169.

20. Van Ravenzwaay, B.; Landsiedel, R.; Fabian, E.; Burkhardt, S.; Strauss, V.; Ma-Hock, L.

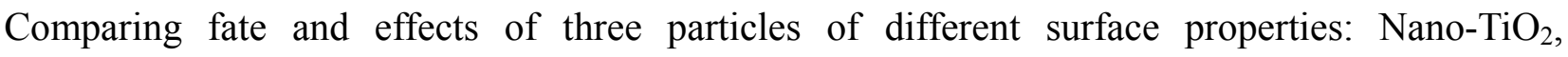
pigmentary $\mathrm{TiO}_{2}$ and quartz. Toxicol. Lett. 2009, 186, 152-159. 
21. Ambalavanan, N.; Stanishevsky, A.; Bulger, A.; Halloran, B.; Steele, C.; Vohra, Y.; Matalon, S. Titanium oxide nanoparticle instillation induces inflammation and inhibits lung development in mice. Am. J. Physiol. 2013, 304, L152-L161.

22. Eydner, M.; Schaudien, D.; Creutzenberg, O.; Ernst, H.; Hansen, T.; Baumgärtner, W.; Rittinghausen, S. Impacts after inhalation of nano- and fine-sized titanium dioxide particles: Morphological changes, translocation within the rat lung, and evaluation of particle deposition using the relative deposition index. Inhal. Toxicol. 2012, 24, 557-569.

23. Lee, S.; Kim, M.S.; Lee, D.; Kwon, T.K.; Khang, D.; Yun, H.S.; Kim, S.H. The comparative immunotoxicity of mesoporous silica nanoparticles and colloidal silica nanoparticles in mice. Int. J. Nanomed. 2013, 8, 147-158.

24. Park, E.J.; Yoon, J.; Choi, K.; Yi, J.; Park, K. Induction of chronic inflammation in mice treated with titanium dioxide nanoparticles by intratracheal instillation. Toxicology 2009, 260, 37-46.

25. Wang, X.; Podila, R.; Shannahan, J.H.; Rao, A.M.; Brown, J.M. Intravenously delivered graphene nanosheets and multiwalled carbon nanotubes induce site-specific Th2 inflammatory responses via the IL-33/ST2 axis. Int. J. Nanomed. 2013, 8, 1733-1748.

26. Gustafsson, A.; Lindstedt, E.; Elfsmark, L.S.; Bucht, A. Lung exposure of titanium dioxide nanoparticles induces innate immune activation and long-lasting lymphocyte response in the Dark Agouti rat. J. Immunotoxicol. 2011, 8, 111-121.

27. Larsen, S.T.; Roursgaard, M.; Jensen, K.A.; Nielsen, G.D. Nano titanium dioxide particles promote allergic sensitization and lung inflammation in mice. Basic Clin. Pharmacol. Toxicol. 2010, 106, 114-117.

28. Chang, X.; Fu, Y.; Zhang, Y.; Tang, M.; Wang, B. Effects of Th1 and Th2 cells balance in pulmonary injury induced by nano titanium dioxide. Environ. Toxicol. Pharmacol. 2013, 37, 275-283.

29. Zárybnická, L.; Vávrová, J.; Havelek, R.; Tichý, A.; Pejchal, J.; Sinkorová, Z.; Lymphocyte subsets and their H2AX phosphorylation in response to in vivo irradiation in rats. Int. J. Radiat. Biol. 2013, 89, 110-117.

(C) 2014 by the authors; licensee MDPI, Basel, Switzerland. This article is an open access article distributed under the terms and conditions of the Creative Commons Attribution license (http://creativecommons.org/licenses/by/3.0/). 